\title{
Concept of the World in the Prose of Zakhar Prilepin (On the Problem of the Creative Personality Evolution)
}

\author{
Natalia S. Tsvetova* \\ St. Petersburg State University \\ 26 1-st. line, St. Petersburg, 199053, Russia
}

Received 27.11.2014, received in revised form 13.01.2015, accepted 06.02.2015

The paper is devoted to "Abode", novel by Zakhar Prilepin, in which creative individuality of the famous writer is revealed from an unexpected side. The author reconstructs the writer's conception of the world through its embodiment in the plot, poetics and style of the text, being convinced that this work with its artistic transformation of reality denies game deliberateness of postmodern, while preference is given to the system of conventions and constraints, relevant to artistic principles of "new realism".

Keywords: "new realism", literary trend, context, concept, character, plot, meaning, dialogue, point of view.

Research area: philology.

Zakhar Prilepin is a novelist, literary scholar, literary critic, essayist, businessman, actor, and musician. Today he is the most significant media person, according to the magazine "Russian Reporter", and one of the most influential in modern Russia. By coincidence of a number of circumstances Zakhar Prilepin attracted the attention of researchers specializing in mainly modern journalistic discourse. The obvious basis for this kind of scientific interest is the writer's activity as office chief editor of "Svobodnaya Pressa" ("Free Press"), the anchorman in the program on the channel "Dozhd", the journalist of the "Novy Mir", "Literary Studies", "Nash Sovremennik", "Literary Gazette". But media researchers pay attention not to topical features of his published media texts, but to fundamentally new qualitative features of the position of the author, who expresses his attitude to any media, both to where he works and where he doesn't as a platform for open dialogue, which is so unusual, compared with the perestroika era (Blokhin. P. 149).

From our point of view, the true value of Z. Prilepin is related to his self-realization in two guises, philological (of a literary scholar) and literary- artistic. The first incarnation of Z. Prilepin is a theorist of "new realism". The concept of this literary movement as an independent and completely original has been presented in the collected book "The Bookgazer" (M., 2012), which at first glance is composed of disparate texts of contemporary prose and poetry, book reviews, written in the specific situations,

(c) Siberian Federal University. All rights reserved

* Corresponding author E-mail address: cvetova@mail.ru 
compiled under the influence of the desire to share the author's "ideas of what has been the literature of the last decade" (Prilepin, 2012. P. 9). Despite claims about certain restrictions in the prior notice to the book, this work creates a very definite idea of the modern Russian literary landscape, dominated by "new realists". They got known after the 2001 journalistic manifesto "Renunciation of Mourning" by S. Shargunov. In this text, the young writer declared soldierlike: "Realism is not exhausted. Realism, endlessly renewing itself with the very reality, remains magically younger than postmodernism" (Shargunov. P. 216). Idea of inexhaustible realism as an artistic method has been subsequently and brilliantly confirmed by artistic practice of S. Shargunov, R. Senchina, M. Elizarov, S. Samsonov, D. Danilov, G. Sadulaie, A. Rubanov, D. Gutsko, etc. "The fun and aggressive, quarrelsome, obsessively present in the literary space" opposed both liberals and pochvennichestvo. They responded to another social needs, reflected the fresh mass public moods at the beginning of the new millennium : they were not aimed at settling of accounts with the past, but at analyzing the contemporary reality, which is a request for a "new statism" idea (Prilepin, 2012. P. 209), formed under the conditions of Soviet nostalgia and fatigue from liberalism, which overfed people with double standards; this was not the interest in bourgeois values, which were being proclaimed by V. Aksenov and V. Voinovich, but in charisma, bravado, red-brown nonconformism of A. Prokhanov, Yu. Mamleev, E. Limonov; tiredness from "postmodernist mocking" and images of Russians as "brutal and bestlike" (Prilepin, 2012. P. 211).

Although Z. Prilepin himself believes that, despite the fact that "new realists" answered many epochal challenges, yet we can not speak of "new realism" as a literary movement, as "new realists" have not yet formed unified perception of today's reality, there are no uniform principles of its artistic display. For example, S. Shargunov can not be called realist without serious reservations. Z. Prilepin calls his own story "Sankya" utopian. And for the entire literature course he offers such nominative replacements: "free community of politically engaged young Russian people", "new nonconformism", "community of radical conservatives", and at the same time "clinical realism" (Prilepin, 2012. P. 213), or even repelling "aesthetic Russian fascists" (Prilepin, 2012. P. 277).

The directions and currents can be discussed endlessly. But the history of Russian literature proves that the true value of any literary event is determined by the appearance in its environment of the exclusive talent, acquiring the experience of adherents and opponents and managing to rise above this experience. In the case of "new realists" a scale criterion is present literaryhistorical phenomenon, thanks first to the literary achievements of Z. Prilepin, who has already endured rather serious literary evolution, demonstrated the ability to show deep and powerful artistic and philosophical reflection, and most importantly, created an extremely topical and unique realizations of quite traditional for Russian classic literary themes and genres. "I write books about war, about revolution and about love" (Prilepin, 2012. P. 337).

First, today's reader is shocked by Prilepin's hero, who often embodies the image of the autobiographical narrator, "sober and attentive" in relation to the self and the world (Prilepin, 2012. P. 148). The hero has a "real occupation, a lot of work, true work", being sure that only work "makes man" (Prilepin, 2012. P. 31). At the same time he is not ashamed of his gentle attitude to the woman he loves, he knows "what is the son's palm and the daughter's breath". He is grateful to the "happy" people, capable of looking at the 
sun "by heart and eyes" and seeing huge light" (Prilepin, 2013. P. 437). He is free from temptation of "gratuitous bluffs" (Prilepin, 2012. P. 29), he is not an outcast and can keep memories of the past, which are salvific for anyone. This man is amazing to present day and openly admits: "There is no feeling of cold and slush. Shroud of wind, fog and snow does not overtake me" (Prilepin, 2013. P. 395).

Second, Prilepin's narrative manner is no less unique, free from the "old-fashioned" details, suggesting attention to detail, in which lies the "spirit" that "very few people are now able to observe and describe...!" (Prilepin, 2012. P. 156). And the writer gives these details often using metaphors created in violation of the well-known logic of the human perception of the world. For example, Prilepin's heroes' vision captures the darkness, "as thick as sand" (Prilepin, 2013. P. 514). Happiness can be depicted via using strange, intertextual by nature comparison "as tight as a sail" (in the short story "Vein") (Prilepin, 2013. P. 437). It is not by chance that one of the best modern European prose writers G. Grass specially marked "organic nature" of his poetics (Grass).

Third, in Z. Prilepin's prose there is no major conflict of the twentieth century traditionalists, which is known as the conflict of "sensible" and "blessed" (see "The Eldest Son" by A.Vampilov, Shukshin's stories, etc.). He is not so much interested in interpersonal clashes, but rather in various events, which fix "a sense of era and space" (Prilepin, 2012. P. 131), while their social and economic aspects are likely to be dominated by metaphysical and ontological essence. It seems that in the artistic interpretation of these events Z. Prilepin follows his literary teacher L. Leonov, whose prose was once compared with Russian flat cake (by V. Soloukhin): once you bite off a small piece, you will have a mouthful. The author of the most popular today book about L. Leonov, which is recognized as such by the key researchers in this field, said that the task of the artist is not to explain, but to give a great opportunity to feel and to guess (Prilepin, 2010). And in realizing this task the writer focuses on the quip of an Eastern sage: “... that's not the subject, but what is behind it" (Prilepin, 2012. P. 171). He knows how to keep the reader's attention drawn to the subject, which is surrounded by "air", meaning different possibilities for perception.

Fourth, Z. Prilepin despises "fictional tales" and proposes "a rare commodity" to a modern reader, it is "a strong male romance, not eroded by sarcasm" (Prilepin, 2012. P. 363). He does not write books in which "the author grins in each line". He inherits the great Russian literary tradition, fixed in the nineteenth century by N.A. Nekrasov, who calls to leave the irony to those "having lived out their lives" and to those "who have not lived their lives at all". Z. Prilepin follows A.A. Blok, who in the twentieth century devoted a special article to the "curse ailment", which was "distorting the faces of our icons and blackening the shining wounds of our holy saints" (Blokhin. P. 345). Z. Prilepin uses the only form of ironic style, i.e. self-irony, the weapon for strong and smart, and he uses it mostly in journalistic and literary-critical texts in a special function (as a means of revealing the assessment).

And finally, the Z. Prilepin's "verbal gait" (Prilepin, 2012. P. 148) is determined by his special "hearing" (Prilepin, 2012. P. 192), the ability to sense the temperature of the word, to catch "thick twist of speech" of his contemporaries (V. Lichutina), to return the meaning to "simple! human! clear! (note the exclamation marks N. Tsvetova) Words! (Prilepin, 2012. P. 408). Prilepin's heroes are able, for example, in a special way to say "warm' thank... you..." (Prilepin, 2013. P. 452). Graphic fixation of a unique sound in familiar words turns into a reminder of the etymology (Russian "thank you" means "save (us) God"), hiding etiquette formula's deeper 
meanings, forgotten by modern man. Also it must be noted that Prilepin's narrative tone has a great meaning, as it is unhurried, always measured, under any conditions attached to the epic rhythm of eternal life. He has everything alive and living: "The village grimaces its fences, flowers in burdocks, waving linen, hanging on the rope" (Prilepin, 2013. P. 443), at the end of the mystical story "Death Village" the embarrassment of heroes disappears as soon as the bitten apple splashed as alive "from under the teeth" (Prilepin, 2013. P. 521).

But if we analyze recent Z. Prilepin's journalistic and literary-critical texts, we can assume that he himself would probably single out in this system of "marking signs", making him a creative personality. By the way, in an interview to the channel "Culture" the writer called the novel "Abode" (2014) "a novel about a man", about complex process of “understanding man's own essence", during which the main hero comes to the conclusion that Russian national character is static and manifests itself salutarily in those historical moments when the "civilization husk is removed" (Z. Prilepin often uses these words N. Tsvetova) (Herman's Choice - Live 18. 05. 2014).

In our view, "Abode" is obviously a landmark work, which allows us to assert that Russian literature is enhanced by the writer, able to create artistic study of the Russian world, exclusively fragile because of its original subordination to an idea of holiness.

According to Z. Prilepin, model of the world in the twentieth century can be represented by Solovki, an archipelago in the White Sea area, where the spring of 1920 saw the establishment of Soviet power and the creation of Solovki Special Purpose Camp. The writer, having worked for several years in the archives of the Solovki, argues that we know a little about the events that took place in the vast expanses of the archipelago in the 1920-1930s, which is the period described in the novel "Abode"; we know about this period less than about all the previous history of Solovki (Gervais. P. 40).

As if trying to fill in the gaps in the reader's historical consciousness, Z. Prilepin on the pages of this work refers to the actual geographic features, historical events; and inhabits the novelistic space with some highly specific characters. Characters of the novel, for example, include the first head of the camps A. Nogtev and his successor F. Eikhmanis. The author gives very specific facts of life in the camp. Thus, the central plot turn, which saved the life of the main character, is motivated by an attempt (fixed in the document management of Solovki in the mid-1920s) to create a cost-effective production forestry, peat mining, brick manufacturing, mining and processing of marine products, and road construction.

But at some point, the reader inevitably begins to realize that the messages (data) are not so more important as the offered conception of the world, a set of laws, which constructed the proposed image of the world (the location of objects and their attributes, the emergence and development of the situations, the image of events) and the principles that define a language for describing this world (Farino. Pp. 26-36). These laws determine the plot of "Abode", the nature of artistic, textual representation of the author's vision of the Russian world, which made the artist overshadow the event level of the narrative. This vision ascertained asceticism and systematic filling of the space with objects, key and constitutional characteristics of time, which affected the form of speech finally.

The semantic basis of artistic model of Solovki is formed slowly and gradually, applying conflicting points of view, with the participation of many key characters, trying to somehow influence the worldview of the central character, 
Artem, 27, a prisoner, who became a guide to the reader. Thanks to Artem, we learn that for the founder of the Russian concentration camps Eikhmanis, who provoked "a sense of tough respect" (Prilepin, 2014. P. 10) Solovki is a huge production, whereas for the former White officer Burtsev, on the contrary, Solovki is "a reflection of Russia, as if through a magnifying glass" (Prilepin, 2014. P. 58). Artem says the metaphor, containing the essence of a unique space, the metaphor was invented by forever philosophizing Mezernitsky: "They just wear a fur coat inside out now! This is Solovki!" (Prilepin, 2014. P. 230). Experienced Vasily Petrovich as if summarizes different impressions: "This is not a laboratory. And it is not hell. This is the circus in hell", phantasmagoria - boundless world, opposed to Russia, the world filled with "a sense of the presence of enemies" (Prilepin, 2014. P. 118), anguish and danger, lying under heavy and close sky, the main attractions of which in the narrator's perception are mirages and mazes. It is appropriate to recall that the old legend say that the souls of the dead move spirally in the labyrinth (Kuznetsova. P. 33).

The Solovetsky world had lost understanding of the real historical time. People who inhabit it, deliberately cut themselves from their past, tending not to think about the future. Timeless sense of the new inhabitants of the monastery is directly related to space, lost in a world of infinity and absorbing their consciousness.

And despite the fact that the writer knows that in reality the Solovetsky archipelago consists of highly diverse natural and historical territories, the narrator forgets about it, because he becomes a performer of the author's paramount task, which involves identifying the commonality of all the camp areas, signs, providing spatial unity. And he discovers and captures these signs clearly: "the swamp white glow of Solovki at night" (Prilepin, 2014. P. 81), "a huge boulder, smelling water, grass, great time, prisoners inside it" (Prilepin, 2014. P. 323), rowan, not gold, although "covered with gold red domes of the Kremlin" (Prilepin, 2014. P. 375). There is a feeling that $Z$. Prilepin primarily draws attention to the "perverted" spatial signs, the principal of which is the sun, having got a cold and rising and setting "almost in the north" (Prilepin, 2014. P. 371), the heaven dome sucking all the life-giving smells and reaching out "to the left and right, rotating, like a children pinwheel" (Prilepin, 2014. P. 409) and "nasty" seagulls with their "greedy femmy, boorish nature" (Prilepin, 2014. P. 409).

Z. Prilepin not only detects but also interprets the found sign, depriving the world of the monastery the aesthetic principle, notwithstanding the fact that this world reflects in a "magnifying glass" what is happening in great Russia, the "natural, unpleasant, visual" world (Prilepin, 2014. P. 58). Poeticisms appear in the text timidly and only in that moment, when in the development of island space the protagonist gets to the heart of Solovki, a cell of the future Orthodox Patriarch Philip, the founder of the monastery. They appear after Artem's bitterly ironic remark that he found himself in this extremely important for the history of Russian spiritual place "without a cross and without a tail" (Prilepin, 2014. P. 371), driven by the fear of death. And Artem does not find any internal resources to adopt the existential security, proposed by fate. Artem's senior fellow (Vasily Petrovich) notes catastrophic internal losses and transformations with bitterness and great compassion: "You had the courage, but there was no malice. There was laughter, but it was not sarcasm. There was the mind, but also there was nature... And what is now?" (Prilepin, 2014. P. 325).

Image of human degradation of this type does not tolerate any pathetic touch or verbosity. And the author's assessment of what is happening provokes selection of strict and ascetic writing 
style, involving minimization of the use of such powerful artistic means as a metaphor. Life in Solovki for Z. Prilepin consists of daily events and facts that determine the existence and, feeling this feature the writer as if follows the call of Father Joannes, who had a powerful impact on the evolution of the personality of the protagonist - "muscovite and buster, reader of books” (Prilepin, 2014. P. 119 ): “... do not look for specific words... take which lie in the heart - the uppermost. Special words are often from the evil one" (Prilepin, 2014. P. 144). At the same time the writer's position can not be called purist. His characters tend to use invective vocabulary, even obscene, but, strange to say, "dangerous" words and expressions get the "semantic husk" away and show the reader their original functionality, communicative kernel associated with the ability to extrapolate emotive tension of a dialogue and momentary emotional outburst of a character.

The most part of the text is "painful", "torn dialogues", involving the central character in one way or another (Prilepin, 2014. P. 321). But each of these dialogues has quite certain semantic dominant, connected with the information waves of Russian media space of the last two decades. Disputes of heroes about the number of those who died in Solovki camps, about camp relationships, about specially created on Solovki "educational" system, about its historical origins, about the mysteries of national character and features of the Soviet social relations reveal the communicative focus of the plot. Some characters offer a very rational point of view (as Eikhmanis, the camp's founder). Father Joannes is wholly convincing as a propagandist of evangelical postulates. Mezernitsky's monologues are rather significant, although it is obvious that he "has consistently said mutually exclusive things" (Prilepin, 2014. P. 32). The protagonist comments on these monologues in his inner speech with the help of many interrogative sentences, syntactic constructions, which are open or completed with periods of ellipsis - artistic device with a definite semantic function - syntactic signal that displays the position of the author, who invites the reader to the unhurried contemplation, encouraging the hope for the future.

These dialogues and reflections have been provoked by the author's conception of the depicted world, world-hell. What is the meaning of this image? Z. Prilepin puts his own interpretation of the most important task into the mouth of Father Joannes: "If the Lord shows you all this disorder, it means He wants to awaken you to restore the order in your heart" (Prilepin, 2014. P. 168). Restoration of order in human hearts for Z. Prilepin is apparently a problem related to national salvation: "You have not sinned today Russia persisted" (Prilepin, 2014. P. 185).

The growing popularity of $Z$. Prilepin suggests that apparently there is a new literary era that does not accept games deliberateness of postmodern and prefers a different system of conventions and constraints that transform reality in accordance with the principles of "new realism". This era brings a different type of writer who has the power necessary to restore the lost life instinct. The writer can be described by the true statement which Z. Prilepin formulates: the writer succeeds, "because he has eaten his words, paid in kind and dictated the book from reality and everyday life..." (Prilepin, 2012. P. 249). And the fact that "he doesn't know how to write good prose" does not prevent him to write it (Prilepin, 2012. P. 166). 


\section{References}

1. Blokhin, I.N. (2014). Novyi realism kak otvet pokusheniiam na real'nost' ("New Realism" as a Response to Assaults On Reality). Dzurnalistika XXI veka: $k$ pravde dzizni [XXI Century Journalism: to the truth of life]. St. Petersburg. Pp. 144-153, 149.

2. Prilepin, Z. Knigochet. Posobie po noveishei literature s liricheskimi i sarkasticheskimi otstupleniiami [The Bookgazer. Manual for the most recent literature with lyrical and sarcastic digressions]. M., 2012. 445 p.

3. Shargunov, S. (2001). Otritsanie traura (Denial of Mourning). Novyi Mir, No. 12. Pp. 214218.

4. Prilepin, Z. Doroga v dekabre [Road in December]. All prose in one volume. M., 2013. $1053 \mathrm{p}$.

5. Grass, G.: Zakhar Prilepin's story "Vein" is a very poetic text, and this poetics is not imposed, but authentic. The main story character is isolated from the world, being "as strange as a meteorite". And this distance is the most powerful thing in the story. Electronic resource (date of reference: 10.05.2014). Mode of Access: http//www. zaharprilepin/ru (official site).

6. Prilepin. Z. Leonid Leonov. Igra ego byla ogromna [Leonid Leonov. His Skill Was Huge]. Series "Lives of Great People". M., 2010. 321 p.

7. Blok, A.A. Irony. Collected Works in 8 Volumes. Vol. 5. Moscow-Leningrad, 1962. Pp. 345350 .

8. Gervais, N. (2007). Solovetskii arkhipelag v prostranstve Belomor'ia (Solovetsky archipelago in the White Sea area). Sofia, No.4. Pp. 33-40.

9. Farino, E. Vvedenie v literaturovedenie [Introduction to Literary Studies]. St. Petersburg, 2004. $639 \mathrm{p}$.

10. Prilepin, Z. Obitel'. Roman [Abode. Novel]. M., 2014. 746 p.

11. Kuznetsova, A. (2006). V poiskakh Slova. Prostranstvo nashei dushi (In search for Word. The space of our soul) Sofia, No. 3. Pp. 32-33. 


\section{Концепция мира в прозе Захара Прилепина \\ (К проблеме эволюции творческой индивидуальности)}

Н.С. Цветова

Санкт-Петербургский государственный университет Россия, 199053, Санкт-Петербург, 1-линия, 26

Статья посвящена роману Захара Прилепина «Обитель», в котором творческая индивидуальность известного прозаика проявилась с неожиданной стороны. Автор статьи реконструирует писательскую концеепию мира через ее воплощение в сюжете, поэтике и стилистике текста, исходя из убеждения в том, что в этом произведении при художественном преобразовании действительности отрицается игровая нарочитость постмодерна, предпочтение отдается системеусловностейиограничений, соответствующим художественным принциипам «нового реализма».

Ключевые слова: «новый реализм», литературное течение, контекст, концепция, персонаж, сюжет, смысл, диалог, точка зрения.

Научная специальность: 10.00.00 - филологические науки. 